\title{
FROM HORIZONTAL TO VERTICAL: AN INTERMEDIARY LIABILITY EARTHQUAKE IN EUROPE
}

\author{
Giancarlo F. Frosio*
}

THE AUTHOR

Giancarlo Frosio, SJD, is a Senior Researcher and Lecturer at the Center for International Intellectual Property Studies (CEIPI) of Strasbourg University. He is also a Non-Resident Fellow at Stanford Center for Internet and Society, Adjunct Faculty at Harvard CopyrightX, Lecturer at the LL.M. in IP law jointly organized by WIPO and Turin University, and Faculty Associate at the Nexa Center for Internet and Society.

\section{THIS ARTICLE}

As part of its Digital Single Market Strategy, the European Commission would like to introduce vertical regulations, replacing-or better conflicting with-the well-established eCommerce Directive horizontal intermediary liability regime.

An upcoming revision of the Audio-visual Media Services Directive would ask platforms to put in place measures to protect minors from harmful content and to protect everyone from incitement to hatred. Meanwhile-under the assumption of closing a 'value gap' between rightholders and online platforms allegedly exploiting protected content-the Draft Directive on Copyright in the Digital Single Market would implement filtering obligations for intermediaries. Finally, the EU Digital Single Market Strategy has also endorsed voluntary measures as a privileged tool to curb illicit and infringing activities online.

Each of these actions will erode the eCommerce intermediary liability arrangement by bringing in -in a way or another-proactive monitoring obligations and causing a systemic shift from a negligence-based to a strict liability regime for hosting providers. This systemic shift would apparently occur against public consensus and absent any justification based on empirical evidence. Nonetheless, it will bring about dire consequences by pushing privatization of enforcement online through algorithmic intelligence, based on murky, privately-enforced standards, rather than transparent legal obligations. This reform might cause a policy earthquake that will shake and crack EU law's systemic consistency, due process and fundamental rights online.

\section{Introduction}

Recalibration towards more secondary liability for online intermediaries does characterize the recent international policy debate. Liability exemptions for online service provides have been a long-lasting companion of Internet policy for the past twenty years. ${ }^{1}$

\footnotetext{
*Email: gcfrosio@ceipi.edu. Please note that most links to online resources are embedded in the text of the footnotes.

${ }^{1}$ See eg Copyright Legislation Amendment Act 2004 (Cth), No. 154, Sch. 1 (Australia); Copyright Modernization Act, SC 2012, c20, § 31.1 (Canada); Judicial Interpretation No 20 [2012] of the Supreme
} 
Traditionally, safe harbor legislations provide mere conduit, caching, and hosting exemptions for intermediaries, together with the exclusion of a general filtering or monitoring obligation. ${ }^{2}$ Nonetheless, the European Commission would like to re-consider the eCommerce Directive horizontal intermediary liability regime and put in place a 'fit for purpose' regulatory environment. ${ }^{3}$ As to be seen in the next few pages, this might bring about a tremendous change in intermediary liability regulation in Europe. In particular, this move from a horizontal intermediary liability regulation to vertical regulations would cause-absent the necessary coordination-such an earthquake in European digital policy to open numerous chiasms and internal inconsistencies.

\section{Re-shaping Intermediary Liability in the Digital Single Market}

The Digital Single Market Strategy (DSMS) aims at moving the European Union from 28 national markets 'towards a connected digital single market' by 'bringing down barriers to unlock online opportunities'. ${ }^{4}$ The DSMS covers a variety of policy topics. Along with e-commerce and telecom rules, cross-border sales, ${ }^{5}$ interoperability and standardization, proposed reforms include copyright and the role of internet service providers (ISPs). In particular, the Commission noted that 'the rules applicable to activities of online intermediaries in relation to copyright protected works require clarification, given in particular the growing involvement of these intermediaries in content distribution' ${ }^{6}$ In addition, the Commission continued, 'measures to safeguard fair remuneration of creators also need to be considered in order to encourage the future generation of content'. ${ }^{7}$ In particular, the Commission is discussing what regulations should apply to a subset of those intermediaries deemed 'online platforms' and 'whether to require intermediaries to exercise greater responsibility and due diligence in the way

People's Court on several issues concerning the application of law in hearing civil dispute cases involving infringement of the right of dissemination on information networks, December 17, 2012 (China); Council Directive (EC) 2000/31 on certain legal aspects of information society services, in particular electronic commerce, in the Internal Market [2000] OJ (L 178) 1-16 [hereinafter eCommerce Directive]; Federal Law No. 149-FZ, on information, information technologies and protection of information, July 27, 2006 (Russia) and Federal Law No. 187-FZ of July 2, 2013 amending Russian Civil Code, § 1253.1 (Russia); Communications Decency Act of 1996, 47 USC $\S 230$ (United States) and The Digital Millennium Copyright Act of 1998, 17 USC $\S 512$ (United States) [hereinafter DMCA]. For full reference to most worldwide safe harbor legislations, see The World Intermediary Liability Map (WILMap), <http://cyberlaw.stanford.edu/our-work/projects/world-intermediary-liability-map-wilmap> (a project designed and developed by Giancarlo Frosio and hosted at Stanford CIS).

${ }^{2}$ See eg eCommerce Directive (n 1) Art 12-15; DMCA, (n 1) § 512(c)(1)(A-C).

${ }^{3}$ See Commission, 'A Digital Single Market Strategy for Europe' (Communication) COM (2015) 192 final, $\S 3.3$ [hereinafter DSM Strategy].

${ }^{4}$ See European Commission, Priority, Digital Single Market < http://ec.europa.eu/priorities/digital-singlemarket en>.

${ }^{5}$ See Commission, 'Proposal for a Council Regulation on addressing geo-blocking and other forms of discrimination based on customers' nationality, place of residence or place of establishment within the internal market and amending Regulation (EC) No 2006/2004 and Directive 2009/22/EC' COM (2016) 289 final.

${ }^{6}$ DSM Strategy (n 3) $§ 2.4$.

7 ibid 
they manage their networks and systems - a duty of care. ${ }^{8}$ The Commission would like to introduce enhanced obligations for Internet intermediaries dealing with unlawful thirdparty content, such as child pornography, terrorist materials, and content that infringes upon intellectual property rights. ${ }^{9}$

The DSMS Communication was followed by several other actions, which were especially relevant for intermediary liability. First, the Commission released a new Communication, Towards a Modern, More European Copyright Framework, ${ }^{10}$ anticipating that policy and legislative action would be taken across a wide range of topics, including 'follow the money' strategies, commercial-scale infringements, application of provisional and precautionary measures, injunctions and their cross-border effect, and notice and action mechanisms and the issue of action remaining effective over time - the 'take down and stay down' principle. ${ }^{11}$

Meanwhile, the Commission also launched a public consultation on the enforcement of intellectual property rights, which is also discussing reform that will affect liability of online intermediaries. ${ }^{12}$ Provisions established by the Enforcement Directive - such as the right of information, legal actions, damages and costs, and provisional and precautionary measures and injunctions-might soon be revisited. ${ }^{13}$ In particular, injunctions against online intermediaries might be considered in the next round of reforms. European law might be amended by explicitly establishing that all types of intermediaries can be injuncted and no specific responsibility - such as violation of any duty of care-would be required to issue an injunction. ${ }^{14}$ Apparently, the Commission might also like to clarify - or update - the European Court of Justice's position in Telekabel. ${ }^{15}$ First, the Commission might introduce criteria for defining the proportionality of an injunction. ${ }^{16}$ Additionally, the Enforcement Directive might be amended to clarify how to balance the effective implementation of a measure and the right to freedom of information of users in case of a blocking order that does not specify the measures which a service provider must take. ${ }^{17}$

\footnotetext{
8 ibid $\S 3.3 .2$; see also eCommerce Directive (n 1) Whereas 48 (previously establishing that ' $[\mathrm{t}] \mathrm{his}$ Directive does not affect the possibility for Member States of requiring service providers, who host information provided by recipients of their service, to apply duties of care, which can reasonably be expected from them and which are specified by national law, in order to detect and prevent certain types of illegal activities').

${ }^{9}$ DSM Strategy (n 3) § 3.3.2.

10 See Commission, Towards a Modern More European Copyright Framework (Communication) COM (2015) 260 Final, 22-23.

11 ibid, at 10-11.

${ }^{12}$ See Commission, 'Public Consultation on the Evaluation and Modernisation of the Legal Framework for the Enforcement of Intellectual Property Rights' (9 December 2015).

${ }^{13}$ See Council Directive (EC) 2004/48 on the enforcement of intellectual property rights [2004] OJ (L 195) 16 (Corrigendum) [hereinafter Enforcement Directive], art 3, 8, 9, 11, 13, and 14.

14 See Commission (n 12) C.2.3.

15 See Case C-314/12 UPC Telekabel Wien GmbH v Constantin Film Verleih GmbH and Wega Filmproducktionsgesellschaft mbH [ 2014] ECLI:EU:C:2014:192.

16 ibid

17 ibid
} 
At about the same time, the Commission launched a public consultation on the role and responsibilities of online intermediaries and platforms, a term which includes a broad range of websites and online services. ${ }^{18}$ The consultation raised a number of pointed questions about the intermediary liability framework in the EU. ${ }^{19}$ In particular, Section 3 of the Consultation, Tackling Illegal Content Online and the Liability of Online Intermediaries, allowed to make a number of predictions regarding critical changes of the regulatory environment for intermediaries that might have been under review. It included questions about whether the E-Commerce Directive's reference to 'mere technical, automatic, and passive' activity by intermediaries is sufficiently clear; ${ }^{20}$ whether additional categories of intermediaries should be established; ${ }^{21}$ whether particular types of content merit different notice-and-action procedures; ${ }^{22}$ and whether action should include 'take down and stay down' or prospective monitoring for flagged content; ${ }^{23}$ and whether there should be imposed specific duties of care for certain intermediaries. ${ }^{24}$

\section{From Horizontal to Vertical Intermediary Liability in Europe}

After the publication of the results of the Consultation on Online Intermediaries, ${ }^{25} \mathrm{a}$ consensus emerged that the existing regime is considered fit for purpose. Therefore, the Commission published a Communication on Online Platforms and the Digital Single Market [OP\&DSM Communication] that apparently endorses the plan of maintaining the existing intermediary liability regime. ${ }^{26}$ However, this broad programmatic statement might be deceiving. Changes might soon come - in terms of expansion of liability for copyright infringement and other categories of illegal content-as the Commission stresses that 'a number of specific issues relating to illegal and harmful content and activities online have been identified that need to be addressed.' 27

In this context, the Commission would launch a 'sectorial legislation [...] and problem-driven approach.' ${ }^{28}$ The Commission was considering for some time whether different categories of illegal content might require different policy approaches.

18 See Commission, 'Public consultation on the regulatory environment for platforms, online intermediaries, data and cloud computing and the collaborative economy' (24 September 2015).

19 ibid, at 5.

$20 \mathrm{ibid}$, at 18 (according to the consultation liability expansion might occur by redefining the notion of 'mere technical, automatic and passive nature' of information transmission by information society service providers so that to exclude some online intermediaries increasingly involved with content distribution, such as video sharing websites). See also eCommerce Directive, (n 1) Whereas 42.

${ }^{21}$ Commission (n 18) 19.

22 ibid 19-21.

23 ibid 20-21.

24 ibid 21-23.

${ }^{25}$ See Commission, 'Full report on the results of the public consultation on the regulatory environment for platforms, online intermediaries and the collaborative economy' (25 May 2016).

${ }^{26}$ See Commission, 'Online Platforms and the Digital Single Market: Opportunities and Challenges for Europe' (Communication) COM (2016) 288 Final, at 9.

27 ibid 8.

28 See Commission (n 26) 8. 
Apparently, this sectorial action will target copyright-protected content, minors' protection from harmful content, and incitement through hatred. ${ }^{29}$ This should happen through a mix of legislative interventions - by updating the audiovisual and copyright regulations - and promotion of voluntary self-regulatory actions. ${ }^{30}$

As part of its legislative intervention package, the Commission will tackle the proliferation on online video sharing platforms of content that is harmful to minors and of hate speech with its proposal for an updated Audio-visual Media Services Directive. ${ }^{31}$ This specific-sector regulation would ask platforms put in place measures to protect minors from harmful content and to protect everyone from incitement to hatred. ${ }^{32}$ Apparently, the AVMS revision might confirm a trend in expanding intermediary liability and limiting exemptions the AVMS. It might erode the eCommerce directive's no monitoring obligations for video platforms by asking Member States to "ensure by appropriate means that audiovisual media services provided by media service providers under their jurisdiction do not contain any incitement to violence or hatred' ${ }^{33}$

\section{Secondary Copyright Liability in Search of Empirical Evidence in the Digital Single Market}

The OP\&DSM Communication anticipated modifications in the balance of copyright in favor of rightsholders as the Commission would aim to achieve a fairer allocation of value generated by the distribution of copyright-protected content by online platforms. ${ }^{34}$ The Commission presented this platform-sensitive update of the EU copyright policy in a proposal for a Directive on Copyright in the Digital Single Market, ${ }^{35}$ which is part of a larger package aiming at modernizing EU copyright rules and achieving a fully functioning Digital Single Market. ${ }^{36}$

The draft directive aims-inter alia - to close the so called 'value gap' between Internet platforms and copyright holders. ${ }^{37}$ The idea of a 'value gap' echoes a discourse

\footnotetext{
29 ibid

30 ibid

${ }^{31}$ See Commission, Proposal for a Council Directive amending Directive 2010/13/EU on the coordination of certain provisions laid down by law, regulation or administrative action in Member States concerning the provision of audiovisual media services in view of changing market realities, COM(2016) 287 final.

32 ibid art 6 and 28.

33 ibid art 6.

${ }^{34}$ Commission (n 26) 8.

${ }^{35}$ Commission, 'Proposal for a Council Directive on Copyright in the Digital Single Market' COM (2016) 593 final, art 13.

36 See Commission, Digital Single Market, Modernization of the EU Copyright Rules <http://bit.ly/DSMCopyright16>.

${ }^{37}$ Possibly, the same rhetoric will be soon redeployed in the United States. In an open letter to Presidentelect Donald Trump, the music industry sought reform of safe harbour legislation, pointing out that hightech companies have thrived on 'free' music and the 'value grab.' See Letter to Donald J. Trump, PresidentElect of the United States from Nineteen Music Industry Organizations (December 13, 2016) $<$ http://arstechnica.com/wp-content/uploads/2016/12/Letter-to-POTUSE-from-Music-Community121316.pdf>.
} 
almost exclusively fabricated by the music and entertainment industry. Apparently, this rhetorical device was coined for the first time in music industry global reports. ${ }^{38}$ After unsuccessful attempts to seek judicial redress against UGC platforms, ${ }^{39}$ the industry decided to plead its case before the legislators and seek law reform. Rightholders would complain that - because of liability exemptions, no monitoring obligations, and the notice and take-down regime - they have no ability to monetize exchange of protected content on user-generated content platform. Rather than entering into licencing agreements, UGC platforms can offer to remove infringing content upon notice-or possibly implement voluntary measures as YouTube Content ID. In turn-according to rightholders-other platforms whose primary business is to sell content to users would be willing to pay less in licencing fees in order to remain competitive with UGC platforms. ${ }^{40}$

This rhetoric seems scarcely concerned with empirical evidence. The European Copyright Society stressed this point by noting: 'we are disappointed to see that the proposals are not grounded in any solid scientific (in particular, economic) evidence. ${ }^{41}$ Actually, the Draft Directive's Impact Assessment itself admits lack of empirical support quite plainly:

economic impacts are mostly assessed from a qualitative point of view, considering how the different policy options would affect the negotiations between those creating or investing in the creation of content and those distributing such content online. The limited availability of data in this area [. . .] did not allow to elaborate a quantitative analysis of the impacts of the different policy options. ${ }^{42}$

In general, there is no clear evidence on the effects of copyright infringement in the digital environment, the scale of it, the nature of it, or the effectiveness of more aggressive enforcement strategies. In an authoritative report commissioned by the UK government, Digital Opportunity. A Review of Intellectual Property and Growth, Professor Ian Hargreaves noted that there is a disconnection between copyright policies to tackle piracy should and transparent empirical evidence:

The question is: in a digital world, where copying and distribution are more or less free, what does an effective regime look like? No one doubts that a great deal of copyright piracy is taking place, but reliable data about scale and trends is surprisingly scarce.

\footnotetext{
${ }^{38}$ See Martin Husovec, 'EC Proposes Stay-down \& Expanded Obligation to Licence UGC Services' (Hut'ko's Technology Law Blog, 1 September 2016) <http://www.husovec.eu/2016/09/ec-proposes-staydown-expanded.html>.

${ }^{39}$ See, eg, GEMA v. Google, 29 U 2798/15 (Higher Regional Court Munich (OLG), January 28, 2016) (Germany) (deciding that YouTube and its service cannot be called to account for any copyright infringements, instead, the judges found that the sole responsibility lies with individual uploaderstherefore YouTube is presently not held financially accountable within the current legal framework when works protected by copyright are used on the platform).

${ }^{40}$ See Husovec (n 38) (making an interesting point by noting that '[i]f hosts see notice-and-takedown as a real alternative to negotiations with right holders, perhaps it indicates that the music is not so indispensable for the online service. Right holders can expose services without such agreements to more enforcement, and so if the music would be so crucial, notorious take-downs would destroy its business.')

${ }^{41}$ European Copyright Society, General Opinion on the EU Copyright Reform Package (24 January 2017) 5 .

${ }^{42}$ Commission, 'Staff Working Document, Impact Assessment on the Modernisation of EU Copyright Rules’ SWD (2016) 301 final, PART 1/3, p 136.
} 
Estimates of the scale of illegal digital downloads in the UK ranges between 13 per cent and 65 per cent in two studies published last year. A detailed survey of $U K$ and international data finds that very little of it is supported by transparent research criteria. Meanwhile sales and profitability levels in most creative business sectors appear to be holding up reasonably well. We conclude that many creative businesses are experiencing turbulence from digital copyright infringement, but that at the level of the whole economy, measurable impacts are not as stark as is sometimes suggested.$^{43}$

In setting up the Commission's reformation process and goals, clear empirical evidence should have been carefully reviewed to consider whether creators - and the creative market as a whole-have been slowly withering or rather flourishing. So far, independent empirical evidence supporting the present enforcement strategy was never provided. Contrary evidence that might emphasize positive externalities for creativity of the Internet, digitization, and platform economy was equally never considered. Actually, this evidence is plenty. The literature have shown to a certain degree of consistency that there is in fact an added value to promote, rather than a value gap to close. ${ }^{44}$ Empirical studies have shown that in the digital environment, the sky is raising, rather than falling, as far as creative industries are concerned. ${ }^{45}$ Again, piracy have been construed by some as an innovation policy, forcing the market to adapt to user needs. ${ }^{46}$ And, the market did in fact adapt, offering new and more affordable ways to enjoy creativity. Overlooking this empirical evidence-or at least moving forward without an impact statement that would consider all evidence and possible narratives - might result into a reform that will prove obsolete before being implemented, possibly detrimental for the Digital Single Market, rather than beneficial. ${ }^{47}$

\section{Filtering and Monitoring: From Negligence-Based to Strict Liability}

Actually-building upon the shaky grounds of a value gap fabricated by industry assumptions, rather than empirical evidence - the Commission would like to craft a

\footnotetext{
${ }^{43}$ Ian Hargreaves, 'Digital Opportunity. A Review of Intellectual Property and Growth' (May 2011) 10 (emphasis added). See also Joe Karaganis, 'Rethinking Piracy', in Joe Karaganis (ed), Media Piracy in Emerging Economies (Social Science Research Center 2011) 4-11 (making the same point).

${ }^{44}$ See Giancarlo Frosio, 'Digital Piracy Debunked: A Short Note on Digital Threats and Intermediary Liability' (2016) 5(1) Internet Policy Review 1-22 <http://policyreview.info/articles/analysis/digitalpiracy-debunked-short-(n-digital-threats-and-intermediary-liability>

${ }^{45}$ See Michael Masnick and Michael Ho, 'The Sky is Rising: A Detailed Look at the State of the Entertainment Industry' (Floor 64, January 2012) 3 <http://www.techdirt.com/skyisrising> (noting the market for music, film and videos, video games, and books has been blooming through the last decade with the value of the worldwide entertainment industry growing of nearly fifty percent, employment in the U.S. entertainment sector rising by nearly twenty percent, the amount of new content being produced worldwide growing at a tremendous rate in any area of the entertainment industry and, finally, more importantly, the total U.S. household spending that went to entertainment growing of fifteen percent). See also Joel Waldfogel, 'Is the Sky Falling? The Quality of New Recorded Music Since Napster' (VOX, 14 November 2011) <http://www.voxeu.org/index.php? $\mathrm{q}=$ node/ 7274 > .

${ }^{46}$ See Adrian Johns, Piracy: The Intellectual Property Wars from Gutenberg to Gates (U Chicago P 2010).

${ }^{47}$ Scholarly projects have been trying to establish a body of evidence that allows better decision making in the contested copyright policy field. See The Copyright Evidence Wiki: Empirical Evidence for Copyright Policy (Theo Koutmeridis, Kris Erickson, K., Martin Kretschmer eds, CREATe Centre: University of Glasgow 2015) <www.CopyrightEvidence.org>.
} 
reform that will possibly affect the backbone of the European intermediary liability regime. The Draft Directive on Copyright in the Digital Single Market contains an array of controversial offerings, but from an intermediary liability perspective, the most relevant provision is Article 13 on 'Certain uses of protected content by online services'. Put it bluntly, under this provision, user-generated content websites would have to shoulder more responsibility for rooting out infringements and share revenues with creators. On one side, intermediaries 'that store and provide access to large amounts of works [. . .] uploaded by their users' will be requested to enter into revenue-share agreements with right holders and collecting societies. ${ }^{48}$ On the other side, the proposal would impose on the same hosting providers an obligation to implement effective content recognition technologies to prevent the availability of infringing content. ${ }^{49}$

Apparently, the new proposal would apply to active hosting providers. First, the proposal restricts its scope to hosting providers by referring only to those who 'store and provide access' to protected works. If they are not eligible for the liability exemption ex Article 14, eCommerce Directive, they will be obliged to conclude licensing agreements with rightholders. Second, for the exemption not to apply, the proposal assumes that hosting providers must play an active role. In defining an active hosting provider, the proposal states that it must go 'beyond the mere provision of physical facilities. ${ }^{50}$ Then, it redeploys the language in L'Oréal $v$. eBay by noting that 'it is necessary to verify whether the service provider plays an active role, including by optimising the presentation of the uploaded works or subject matter or promoting them, irrespective of the nature of the means used therefor.' ${ }^{51}$

There are several textual issues with this proposal that would need clarification, ${ }^{52}$ however there are major issues that might open chiasms and systemic ruptures in the traditional eCommerce Directive horizontal intermediary liability regime. In this respect, one first especially substantial interpretative headache is given by a novel construction of the notion of communication to the public. ${ }^{53}$ This interpretation might have far-reaching effects on the traditional treatment of intermediary liability for copyright infringement in Europe. The proposal implies that if the hosting providers do not just merely provide physical facilities and play an active role, 'thereby' they do perform an act of communication to the public. ${ }^{54}$ Actually, this reference is not isolated. Apparently, the Commission characterizes platforms as actively 'making available' content uploaded by end-users also elsewhere. In the Communication on Online Platforms and the Digital Single Market, the Commission noted that rebalancing is needed because 'new forms of

\footnotetext{
${ }^{48}$ Commission (n 35) art 13(1).

49 ibid

50 ibid Recital 38.

51 ibid. See also See C-324/09 L'Oréal SA and Others v. eBay International AG and Others $§ 139$ [2011]

${ }^{52} \mathrm{See}$, for a full discussion this textual issues - and an in depth analysis of the proposal, Giancarlo Frosio and Christophe Geiger, 'Reaction of CEIPI to the European Commission's Proposal on Certain Uses of Protected Content by Online Services’ (2017) CEIPI Position Paper.

${ }^{53}$ See Council Directive (EC) 2001/29 on the Harmonisation of Certain Aspects of Copyright and Related Rights in the Information Society [2001] OJ L 167/10-19 [hereinafter InfoSoc Directive], Art. 3(1).

54 ibid
} 
online content distribution have emerged [...] that may make copyright protected content uploaded by end-users widely available ${ }^{55}$ The reasons for this characterization are quite apparent. If platforms communicate to the public, they can be obliged to enter into licencing agreements, rather than monetization agreements on a voluntary basis. However, characterizing hosting providers as "communicating to the public" might hardly fit within theoretical debate on point. ${ }^{56}$ Actually, the inapplicability of the exemptions does not imply as such that information society service providers would be communicating to the public, thus liable. ${ }^{57}$ Instead, the construction of EU law included in the proposal would make active hosts directly liable, rather than secondary liable as commonly understood. As a default rule, end-users are generally understood to be those communicating to the public in the digital environment. ${ }^{58}$ As end-users physically upload the work, they alone apparently can fulfill the requirement of being that necessary intervention enabling the new public to enjoy the protected work. Actually, in some residual circumstances, intermediaries have been held directly liable for their users' copyright infringement, only when their involvement in the infringement is so substantial that they have been found to have communicated the works themselves, rather than being used by others to perform the communication. ${ }^{59}$ However, traditionally, intermediaries have been held secondary liable, rather than primarily. In most EU jurisdiction, secondary liability requires highly demanding conditions that are derived from

\footnotetext{
55 ibid

${ }^{56}$ See Christina Angelopoulos, 'EU Copyright Reform: Outside the Safe Harbours, Intermediary Liability Capsizes into Incoherence' (Kluwer Copyright Blog, 6 October 2016) <http://kluwercopyrightblog.com/2016/10/06/eu-copyright-reform-outside-safe-harbours-intermediaryliability-capsizes-incoherence> (noting that "for a nonchalant statement hidden in a recital, this is quite the dramatic development of EU copyright law"); Christina Angelopoulos, 'On Online Platforms and the Commission's New Proposal for a Directive on Copyright in the Digital Single Market' (2017) 19-33 $<$ https://juliareda.eu/wp-content/uploads/2017/03/angelopoulos_platforms_copyright_study.pdf>; Eleonora Rosati, 'Why a Reform of Hosting Providers' Safe Harbour is Unnecessary under EU Copyright Law' (2016) CREATe Working Paper 11/2016.
}

${ }^{57} I d$.

${ }^{58}$ See C-306/05 Sociedad General de Autores y Editores de España (SGAE) v Rafael Hoteles SA [2006] ECR I-11519, § 42; Joined C-403/08 and C-429/08 Football Association Premier League and Others v. QC Leisure and Others [2011] ECR I-09083, § 195.

${ }^{59}$ Standards have varied greatly from jurisdiction to jurisdiction. See Angelopoulos (2017) (n 56) 23-30. For example, in the UK, there is clear distinction between primary and secondary infringement, which makes a high bar for finding intermediaries directly liable. See Twentieth Century Fox Film Corp v Newzbin Ltd [2010] EWHC 608 (Ch) (UK) (finding an indexing website- used for the illegal exchange of copyrighted movies - directly liable for having communicated works to the public because it had "intervened in a highly material way to make the claimants' films available to a new audience, that is to say its premium members," in particular "by providing a sophisticated technical and editorial system which allows its premium members to download all the component messages of the film of their choice upon pressing a button, and so avoid days of (potentially futile) effort in seeking to gather those messages together for themselves"); Football Association Premier League Ltd v British Sky Broadcasting Ltd \& Others [2013] EWHC 2058 (Ch) (UK) (finding that-in the case of a link aggregator of unlawfully streamed sport events - (i) the aggregation of a large number of streams, (ii) the indexing of those streams for the convenience of the users, (iii) the provision of a simple link to click in order to have access to the stream, and (iv) the fact that the stream is presented in FirstRow's frame or window makes the site directly liable for the communication). 
miscellaneous doctrines of tort law, ${ }^{60}$ such as the doctrines of joint tortfeasance, authorization, inducement, common design, contributory liability, vicarious liability, or extra-contractual liability. ${ }^{61}$ The wording of this proposal would make direct liability for intermediaries the default rule, rather than a residual option. Apparently, intermediary services would automatically be assumed to be infringing and directly liable for infringements materially committed by others.

In order to ensure the functioning of licensing agreements and prevent the availability of infringing content, the proposal would impose to hosting providers the use of effective content recognition technologies, ${ }^{62}$ such as YouTube's Content ID or other automatic infringement assessment systems. The proposal would de facto force intermediaries to develop and deploy filtering systems. In turn, such an obligation would impose general monitoring obligations as to the end of filtering unwanted content, all content must be monitored. ${ }^{63}$

The introduction of any filtering technology would inevitably call into question necessary coordination with the eCommerce Directive. ${ }^{64}$ Awkwardly, the eCommerce Directive is absent from the list of Directives that the Proposal explicitly state that will remain unaffected or whose rules is set to complement. ${ }^{65}$ In this respect, the proposed reform would contradict the intermediary liability exemption regime - in particular the no-monitoring obligation set out in Article 15 of the eCommerce Directive. ${ }^{66}$ In Scarlet

${ }^{60}$ See Kamiel Koelman and Bernt Hugenholtz, 'Online Service Provider Liability for Copyright Infringement' (22 November 1999) WIPO Doc. OSP/LIA/1 Rev.1, at 5-8; BGB [German Civil Code], Art. 830 (governing joint tortfeasance).

${ }^{61}$ Lacking harmonization of secondary liability at the EU level, each Member State has deployed differing and miscellaneous standards. See Christina Angelopoulos, European Intermediary Liability in Copyright. A Tort-Based Analysis (Kluwer Law Int'l 2016); Tatiana-Eleni Synodinou, 'Intermediaries' Liability for Online Copyright Infringement in the EU: Evolutions and Confusions' (2015) 31 Comp L \& Sec Rev 57, 57-67; Mari Männiko, 'Intermediary Service Providers' Liability Exemptions: Where Can We Draw the Line?' in Tanel Kerikmäe (ed), Regulating eTechnologies in the European Union: Normative Realities and Trends (Springer Int'l Publ 2014) (noting that comparative analysis show that the present legislation is too general and gives too much room for interpretation); Christina Angelopoulos, 'Beyond the Safe Habours: Harmonising Substantive Intermediary Liability for Copyright Infringement in Europe' (2013) 3 IPQ 253, 254 (2013); Patrick Van Eecke, 'Online Service Providers and Liability: A Plea for a Balanced Approach' (2011) 48(5) Common Market L Rev 1455, 1457-1461; Broder Kleinschmidt, 'An International Comparison of ISP's Liabilities for Unlawful Third Party Content' (2010) 18(4) Int'l J L \& Inf Tech 332, 345-353.

${ }^{62}$ DSM Directive Proposal (n 35) Recital 38.

${ }^{63}$ See Case C-360/10 Belgische Vereniging van Auteurs, Componisten en Uitgevers CVBA (SABAM) v. Netlog $N V$ [2012] ECLI:EU:C:2012:85, § 36-38 (noting that 'it is common ground that implementation of that filtering system would require [. . . ] active observation of files stored by users with the hosting service provider and would involve almost all of the information thus stored and all of the service users of that provider [. . .] [i]n the light of the foregoing, it must be held that the injunction imposed on the hosting service provider requiring it to install the contested filtering system would oblige it to actively monitor almost all the data relating to all of its service users in order to prevent any future infringement of intellectual-property rights').

${ }^{64}$ See Angelopoulos (2017) (n 56) 34-38.

${ }^{65}$ See DSM Directive Proposal (n 35) Art 1(2) and Recital 4.

${ }^{66}$ See eCommerce Directive (n 1) art 14-15. 
Extended and Netlog, the European Court of Justice confirmed that filtering and general monitoring would be in violation of EU law. ${ }^{67}$ Introducing proactive monitoring solely through copyright regulation-rather than amending the horizontal eCommerce regulation-would open a systemic crack into the EU liability regime. In multiple cases-Scarlet Extended, Netlog as well as L'Oreal-the ECJ decided over the appropriacy and proportionality of injunctions issued under the Enforcement Directive and concluded plainly that the eCommerce Directive limits conflicting measures that can be taken under other intellectual property legislation. ${ }^{68} \mathrm{In}$ addition, this would be done short of any consensus over reforming the no-monitoring obligation principle, as the consultation on platforms made clear. ${ }^{69}$ Actually, changes to an earlier draft of the proposal may prove that the Commission itself would be well aware of this lack of consensus. Originally, the draft Directive extended the application of the filtering obligation also 'when, in accordance with Article 15 of Directive 2000/31/EC, the online service providers do not have a general obligation to monitor the information which they transmit or store or to actively seek facts or circumstances indicating illegal activity. ${ }^{70}$ Finally, this reference to the no-monitoring obligations in Article 15 of the eCommerce Directive was dropped and substituted with an apparently meaningless reference to the hosting exemption in Article 14. ${ }^{71}$

This proposal would bring about an even more substantial systemic inconsistency within EU law, a true earthquake in the horizontal liability regime established by the eCommerce Directive. As such, the proposal would enforce a de facto strict liability regime, rather than a negligence-based regime. ${ }^{72}$ At present, the eCommerce intermediary

\footnotetext{
${ }^{67}$ See Case C-70/10 Scarlet Extended SA v. Société belge des auteurs, compositeurs et éditeurs SCRL $(S A B A M)$ [2011] ECR I-11959 (re-stating the principles in favour of access providers); Netlog (n 63) (confirming the principle in favour of hosting providers).
}

${ }^{68}$ See C-324/09 L'Oréal SA and Others v. eBay International AG and Others $§ 139$ [2011]; Scarlet (67) § $40 ;$ Netlog $(63) \S 52$.

${ }^{69}$ Commission (n 25).

${ }^{70}$ See Husovec (n 38) (embedding in the blog post the previous draft).

${ }^{71}$ See Frosio and Geiger (52) (discussing the point).

72 One might fairly argue here that strict-liability does not descend from third-party copyright infringement but rather from the violation of the stand-alone obligation of taking measures to prevent the availability of infringing works. If this is the case, this might matter a lot as hosting providers might be deemed liable for not implementing measures regardless whether copyright infringement does occur or not. In this respect, hosting providers might be requested to implement measures that prevent the availability of works regardless their privileged use status. The current wording of the proposed Article 13 makes this construction likely by referring to preventing the availability of "works or other subject-matter identified by rightholders through the cooperation with the service providers', rather than copyright protected works or other subject matters. However, the proposal might be harder to decipher in this respect. According to Recital 38, intermediaries do have an obligation to conclude licencing agreements and should take measures to ensure the functioning of those agreements. Prevention of copyright infringement does ensure the functioning of the agreements. Thus, hosting provider should take measures to prevent copyright infringement to ensure the functioning of the licencing agreements. Measures to be taken here are just conducive to enforce the primary obligation to conclude licencing agreements and ensure their functioning through copyright infringement prevention. So, by ineffectively taking measures to prevent availability of infringing works on their networks, hosting providers would be liable for their obligation to conclude and ensure functioning of licencing agreements. As that functioning depends on preventing third-party 
liability regime can be categorized as a negligence regime based on actual or constructive knowledge. ${ }^{73}$ Upon knowledge of the infringement occurring through its services, the intermediary must act expeditiously to remove the infringing materials. ${ }^{74}$ Although not statutorily defined as such, the hosting exemption is based on a notice-or better knowledge — and take down regime. The proposal would make knowledge and take-down irrelevant for copyright purposes, tearing apart the eCommerce Directive. Hosting providers shall be liable for failing to take appropriate and proportionate measures, such as effective content recognition technologies, to ensure protection of copyrighted works and prevent the availability of infringing materials on their networks. Apparently, regardless hosting providers' negligence, ineffective prevention of availability on their network of infringing content would make them liable. As the reform proposal stands, if implemented, it might lead to paradoxical scenarios. Hosting providers might claim that they should not be held liable as they are not negligent according to the eCommerce Directive, while rightholders will claim that their negligence is irrelevant as they should have filtered out infringing content regardless of any knowledge according to the Copyright in the Digital Single Market Directive

Also, introducing a strict liability system for online intermediaries' activities might be itself an inappropriate and disproportionate policy choice as it will upset the delicate balance of copyright protection with other fundamental users' rights. In Google v. Vuitton, the Advocate General of the CJEU pointed at the fact that general rules of civil liability (based on negligence) - rather than strict liability IP law rules-suit best the governance of the activities of Internet intermediaries. His argument-crafted in the context of trademark infringement online-would apply mutatis mutandis to copyright as well:

[1]iability rules are more appropriate, since they do not fundamentally change the decentralised nature of the internet by giving trade mark proprietors general - and virtually absolute - control over the use in cyberspace of keywords which correspond to their trade marks. Instead of being able to prevent, through trade mark protection, any possible use - including, as has been observed, many lawful and even desirable uses trade mark proprietors would have to point to specific instances giving rise to Google's liability in the context of illegal damage to their trademarks. ${ }^{75}$

A negligence-based system would serve better the delicate balance between protection of copyright, access to information, and freedom of expression that the intermediary liability conundrum online entails. As long as they undermine the knowledge and take-down mechanism in place, filtering and monitoring obligations would by default cause chilling

copyright infringement occurring through their networks, an argument can be made that providers'strict-liability steams from those third-party torts. If the proposal is approved as it stands, this teleological interpretation might be preferred in light of the purpose and legal goals of the provision.

${ }^{73}$ See Pablo Baistrocchi, 'Liability of Intermediary Service Providers in the EU Directive on Electronic Commerce' (2002) 19 Santa Clara High Tech. L.J. 111, 114.

${ }^{74}$ See eCommerce Directive (n 1) art 14.

75 Joined cases C-236/08, C-237/08 and C-238/08, Google France SARL and Google Inc. v. Louis Vuitton Malletier SA, Google France SARLv. Viaticum SA and Luteciel SARL and Google France SARL v. Centre national de recherche en relations humaines (CNRRH) SARL and Others (2010) I-02417 § 123 (Advocate General Opinion). 
effects over freedom of information. As Van Eecke mentioned, "the notice-and-takedown procedure is one of the essential mechanisms through which the eCommerce Directive achieves a balance between the interests of rightholders, online intermediaries and users." 76 Notice an-take-down mechanisms embed a fundamental safeguard for freedom of information as long as they force intermediaries to actually consider the infringing nature of the materials before coming down with a final removal decision.

In this respect, a major concern with the proposal is whether these technologies would be 'appropriate and proportionate'. Apparently, they are not. They would rather fail to strike a 'fair balance' between copyright and other fundamental rights. ${ }^{77}$ According to the $\mathrm{ECJ}^{78}$ - they would undermine users' freedom of expression, right to privacy and the provider's freedom to conduct business. ${ }^{79}$ In particular, automatic infringement assessment systems might constrict the enjoyment of users' exceptions and limitations. ${ }^{80}$ Also, complexities regarding the public domain status of certain works might escape algorithmic intelligence. As the ECJ noted filtering technologies "could potentially undermine freedom of information, since that system might not distinguish adequately between unlawful content and lawful content, with the result that its introduction could lead to the blocking of lawful communications." 81

In imposing proactive monitoring obligations to intermediaries, current Internet policy might be silently drifting away from a fundamental safeguard for users' freedom of information and intermediaries' freedom of business. In truth, this proposal follows in the footsteps of a well-established path in recent intermediary liability policy. Recent case law has already imposed filtering and proactive monitor obligations on intermediaries for copyright infringement in multiple instances - such as Allostreaming in France, Dafra in Brazil, RapidShare in Germany, or Baidu in China. ${ }^{82}$ However, this emerging trend is not

\footnotetext{
${ }^{76}$ Van Eecke (n 61) 1479-1480.

${ }^{77}$ See Charter of Fundamental Rights of the European Union, C326/391 (26 October 2012) [hereinafter EU Charter]. See also Angelopoulos (2017) (n 56) 38-40.

${ }^{78}$ See Netlog (n 63) §

${ }^{79} \mathrm{See}$, for a detailed analysis of the inappropriacy of the proposal from a fundamental rights perspective, Frosio and Geiger (n 52).

${ }^{80}$ See eg Justyna Zygmunt, To Teach a Machine a Sense of Art - Problems with Automated Methods of Fighting Copyright Infringements on the Example of YouTube Content ID, Machine Ethics and Machine Law E-Proceedings, Jagiellonin University, Cracow, Poland, November 18-19, 2016, pp. 55-56; Leron Solomon, 'Fair Users or Content Abusers? The Automatic Flagging of Non-Infringing Videos by Content ID on Youtube' (2015) 44 Hofstra L Rev 237; Corinne Hui Yun Tan, 'Lawrence Lessig v Liberation Music Pty Ltd - YouTube's Hand (or Bots) in the Over-zealous Enforcement of Copyright' (2014) 36(6) EIPR 347, 347-351.

${ }^{81}$ Netlog (n 63) § 50.

82 See APC et al v Google, Microsoft, Yahoo!, Bouygues et Al (TGI Paris 2013) (France) $<$ http://static.pcinpact.com/medias/jugement-allostreaming-20131129.PDF> (imposing on search engines an obligation to proactively expunge their search results from any link to the illegal movie streaming website Allostreaming and affiliated enterprises); Google Brazil v Dafra, Special Appeal 1306157/SP (Superior Court of Justice, 24 March 2014) (Brazil) 〈https://cyberlaw.stanford.edu/page/wilmap-brazil > (imposing on YouTube a proactive monitoring obligation and a strict liability standard for infringement of Dafra's copyright in a commercial dubbed by an anonymous user with comments tarnishing Dafra's reputation); GEMA v RapidShare I ZR 80/12 (Bundesgerichtshof, August 15, 2013) (Germany)
} 
limited to copyright policy. Actually, the enforcement of proactive monitoring obligations has been spanning the entire spectrum of intermediary liability subject matters: intellectual property, privacy, defamation, and hate/dangerous speech. ${ }^{83}$ As I argue in more details elsewhere, there might be a well-marked trend in intermediary liability policy leading to the death of 'no monitoring obligations.' 84

\section{Sectorial Notice-and-Take-Down?}

EU law has been long-awaiting a horizontal notice-and-take-down and counter-notice system. ${ }^{85}$ Apparently, this will not come anytime soon. As mentioned in the OP\&DSM Communication, EU-wide notice-and-action procedures will be postponed for now as the Commission will assess the impact of on-going reforms first. ${ }^{86}$ Rather, the Commission might implement a sectorial and problem-driven approach also for notice-and-action procedures with special emphasis on different requirements as regards the content of the

$<$ https://cyberlaw.stanford.edu/page/wilmap-germany> (finding that — under the TMA — host providers are already ineligible for the liability privilege if their business model is mainly based on copyright infringement); Zhong Qin Wen v Baidu, 2014 Gao Min Zhong Zi 2045 (Beijing Higher People's Court 2014) <https://cyberlaw.stanford.edu/page/wilmap-china> (finding that it was reasonable for Baidu to exercise a duty to monitor and examine the legal status of an uploaded work once it has been viewed or downloaded more than a certain times).

83 See Google v Mosley (TGI Paris, 6 November 2013) (France) <http://cyberlaw.stanford.edu/page/wilmap-france>; Max Mosley v Google Inc., 324 O 264/11 (Hamburg District Court, 24 January 2014) < http://openjur.de/u/674344.html >; Mosley v Google [2015] EWHC 59 (QB) (United Kingdom) <http://cyberlaw.stanford.edu/page/wilmap-united-kingdom> (courts in France, Germany, and the UK imposing proactive monitoring obligations to search engines, which were ordered to expunge the Internet from pictures infringing the privacy rights of Max Mosley-former president of Formula 1-caught on camera to have sex with prostitutes wearing Nazi paraphernalia); Rolex v. eBay (a.k.a. Internetversteigerung II), I ZR 35/04 (BGH, 19 April 2007) (Germany); Rolex v. Ricardo (a.k.a. Internetversteigerung III), Case I ZR 73/05, (BGH, 30 April 2008) (Germany) (in the so-called Internet Auction cases I-III, the German Federal Court of Justice-Bundesgerichtshof - repeatedly decided that notified trade mark infringements oblige internet auction platforms such as eBay to investigate future offerings - manually or through software filters - in order to avoid trade mark infringement); Delfi AS v Estonia No 64569/09 (ECtHR, 16 June 2015) 〈http://hudoc.echr.coe.int/eng?i=001-155105> (finding compliant with ECHR a decision imposing monitoring obligation on a news web portal for defamatory users' comments).

${ }^{84}$ A detailed discussion of this trend will be the subject of a forthcoming paper. See Giancarlo F. Frosio, 'The Death of 'No Monitoring Obligations': A Story of Untameable Monsters (forthcoming 2017). In this context, however, notable exceptions - such as the landmark Belen case in Argentina-highlight also a fragmented international reaction. See Rodriguez M Belen v Google, R.522.XLIX. (Supreme Court, October 29, 2014) (Argentina) <https://cyberlaw.stanford.edu/page/wilmap-argentina > (ejecting filtering obligations to prevent infringing links from appearing in search engines' results in the future in a case brought a well-known public figures for violation of her copyright, honor and privacy).

${ }^{85}$ See eCommerce Directive (n 1) Art. 21 (foreseeing the possibility of the introduction of a complete notice-and-take-down procedure); Leaked draft Proposal for a Directive of the European Parliament and of the Council on procedures for notifying and acting on illegal content hosted by online intermediary service providers ("Directive on notice-and-action procedures") [...] (2013) XXX draft (proposing a horizontal notice-and-action mechanism for hosting providers and later floated by the Commission). See also Aleksandra Kuczerawy, 'Intermediary Liability \& Freedom of Expression: Recent Developments in the EU Notice \& Action Initiative' (2015) 31(1) Comp L \& Sec Rev 46.

${ }^{86}$ See Commission (n 26) 9. 
notice. ${ }^{87}$ According to the results of the Consultation on Online Intermediaries, respondents agree that different categories of illegal content require different policy approaches as regards notice-and-action procedures, especially for infringements of intellectual property rights, child abuse content and racist and xenophobic speech. ${ }^{88}$

In the draft Directive, this sectorial approach might find a first representation. Article 13 would like to set up a proactive filtering mechanism that apparently does not seek any individualized notice for infringing works but rather some other identification mechanism-perhaps agreed in advance between rightholders and hosting providers. However, the proposal would also introduce a redress mechanism for disputes over the application of filtering measures. ${ }^{89}$ This would resemble a counter-notice mechanism. How would filtering measures work in practice? Nothing is known. The proposal does not develop further on this point. It does not provide any obligations for the development of best practices or standardization for counter-notices, while it does so for filtering mechanisms. ${ }^{90}$ Should intermediaries filter everything under the sun? Should they proactively monitor what has been originally the subject of a notice? Should they apply recognition technologies only to a pre-existing black list of protected works? This might be the case - at least guessing a possible meaning of the reference in Article 13 to works 'identified by rightholders through the cooperation with the service provider', whose availability should be prevented. ${ }^{91}$ Who will provide that list? Who will update it? How? Once the proposed system will be fully developed, it might actually deploy an arrangement that might resemble closely a sectorial notice-and-take down system. Apparently - as the proposal is silent regarding all this - this notice-an-and-take-down and counter-notice system might result from voluntary efforts and best practices promoted by the industry alone. Rather — as widely suggested-EU law should have set up first the long-awaited horizontal notice-and-take-down and counter-notice system under the eCommerce Directive framework. ${ }^{92}$

\footnotetext{
${ }^{87}$ See Commission (n 18) 19-20. See also Deutschlands Zukunft gestalten - Koalitionsvertrag zwischen CDU, CSU und SPD, 18 Legislaturperiode (December 17, 2013) 133 (stipulating different liability levels for different kind of hosting providers).

${ }^{88}$ See Commission (n 25).

${ }^{89}$ Commission (n 35) art 13(2).

${ }^{90}$ ibid art 13(3). See also Husovec (n 38).

${ }^{91}$ DSM Directive Proposal (n 35) art 13(1). A leaked draft report to the Parliament from the Directive rapporteur, MEP Therese Comodini Cachia, tried to clarify this point by redrafting Article 13 so that for the purpose of taking 'appropriate and proportionate measures to ensure the functioning of agreements concluded with rightholders for the use of their works', 'rightholders shall provide service providers with accurately identified works or subject matter over which they enjoy rights'. See Draft Report by MEP Therese Comodini Cachia on the Directive on Copyright in the Digital Single Market for the Legal Affairs (JURI) Committee 74-76 <https://gallery.mailchimp.com/5d8aa63bf84f94a65300f42e9/files/dfe0d4f4acb4-4843-9157-dd8f9ce7b31f/Copyright_in the_DSM_amendments_JURI.docx>.

${ }^{92}$ See Copyright Reform: Open Letter from European Research Centres, EU Copyright Reform Proposals Unfit for the Digital Age (24 February 2017) <http://bit.ly/2loFISF> and Angelopoulos (2017) (n 56) 43-44 (both suggesting the introduction of an horizontal notice-and-action framework for hosting providers instead of the current Art. 13).
} 


\section{Shaking the eCommerce Safe Harbours on a Voluntarily Basis}

Voluntary measures - which the Commission would like to promote among platforms - do shake the EU intermediary liability system with similar intensity and tightly connected disruptive effects. Hosting providers - especially platforms - would be called to actively and swiftly remove illegal materials, instead of reacting to complaints. In this sense, voluntary measure would also upset the balance in favour of users' rights that the eCommerce Directive's negligence-based intermediary liability system, based on knowledge and take down, attempts to achieve.

The OP\&DSM Communication puts forward the idea that 'the responsibility of online platforms is a key and cross-cutting issue. ${ }^{93}$ In other words, intermediary liability expansion - and limitation of safe harbors-will occur by imposing an obligation on online platforms to behave responsibly by addressing specific problems. This terminology echoes a discourse representing a global move from intermediary liability to intermediary responsibility, with special emphasis on the promotion of voluntary measures from intermediaries to curb undesired conducts - and speech-online. Voluntary measures make intermediaries prone to serve governmental purposes under murky, privately-enforced standards, rather than transparent legal obligations. As EDRi noted private enforcement "downgrades the law to a second-class status, behind the "leading role" of private companies that are being asked to arbitrarily implement their terms of service." 94

This process might be pushing an amorphous notion of responsibility that incentivizes intermediaries' self-intervention to police allegedly infringing activities in the Internet. Apparently, the Commission aligns its strategy for online platforms to a globalized, ongoing move towards privatization of law enforcement online through algorithmic tools. ${ }^{95}$ From a realpolitik policy perspective, this would be an utterly poor bargain for Europe and its Digital Single Market. European legislators would hand in control over sanitization of Internet content to privately owned algorithmic enforcement, totally unaware of how these algorithms work and absent any mechanisms to make private parties controlling the algorithms accountable. There's a multitude of possible dystopian scenarios just to be imagined.

Meanwhile, coordinated EU-wide self-regulatory efforts by online platforms should immediately be directed to fight incitement to terrorism and prevent cyber-bullying. ${ }^{96}$ Actually, as an immediate result of this new policy trend, the Commission recently agreed with all major online hosting providers - including Facebook, Twitter, YouTube and Microsoft — on a code of conduct that includes a series of commitments to combat the

\footnotetext{
${ }^{93}$ Commission (n 26) 9.

94 'EDRi and Access Now withdraw from the EU Commission IT Forum discussions' (EDRi, 16 May 2016) < https://edri.org/edri-access-now-withdraw-eu-commission-forum-discussions>.

95 See Joe McNamee, 'Leaked EU Communication - Part 1: Privatized Censorship and Surveillance' (EDRi, 27 April 2016) <https://edri.org/leaked-eu-communication-privatised-censorship-and-surveillance> .

96 ibid 10.
} 
spread of illegal hate speech online in Europe. ${ }^{97}$ In this context, tech companies plan to create a shared database of unique digital fingerprints-knows as ashes - that can identify images and videos promoting terrorism. ${ }^{98}$ Some EU member States such as Germany may even bring in a law to impose fines of up to $€ 500,000$ on a platform failing to take down illegal content within 24 hours. ${ }^{99}$

On the intellectual property enforcement side, payment blockades-notice-andtermination agreement between major right holders and online payment processors - and "voluntary best practices agreements" for copyright and trademark enforcement have been applied widely, especially in the United States. ${ }^{100}$ Payment processors like MasterCard and Visa have been pressured to act as intellectual property enforcers, extending the reach of intellectual property law to websites operating from servers and physical facilities located abroad. ${ }^{101}$ In the Communication Towards a Modern, More European Copyright Framework, the Commission apparently would like to endorse similar strategies by deploying a 'follow-the-money' approach. ${ }^{102}$ As the Commission noted, this strategy 'can deprive those engaging in commercial infringements of the revenue streams (for example from consumer payments and advertising) emanating from their illegal activities, and therefore act as a deterrent'. ${ }^{103}$ According to the Commission, 'follow-the-money' mechanism should be based on a self-regulatory approach through the implementation of Code of Conducts that might be later backed up by legislation if necessary.

\section{Conclusions}

An earthquake might shake European intermediary liability — and copyright - policy. A directive proposal - together with other reform instruments that will soon follow suithas been submitted for review to the EU Parliament and the Council. This reform planfocusing on the governance of allegedly illegal content online-might shake the

\footnotetext{
${ }^{97}$ See Commission, European Commission and IT Companies Announce Code of Conduct on Illegal Online Hate Speech, Press Release (31 May 2016) <http://europa.eu/rapid/press-release_IP-161937 en.htm>; Commission, Justice and Consumers, Fighting Illegal Online Hate Speech: First Assessment of the New Code of Conduct, Press Release (12 December 2016), $\langle$ http://ec.europa.eu/newsroom/just/item-detail.cfm?item_id=50840 > (urging platforms to do more to implement the code of conduct)

${ }^{98}$ Olivia Solon, 'Facebook, Twitter, Google and Microsoft Team up to Tackle Extremist Content (The Guardian, 6 December 2016) https://www.theguardian.com/technology/2016/dec/05/facebook-twittergoogle-microsoft-terrorist-extremist-content.

${ }^{99}$ Cara McGoogan, 'German Politician Threatens to Fine Facebook $€ 500,000$ Every Time It Shows Fake News' (The Telegraph, 19 December 2016) <http://www.telegraph.co.uk/technology/2016/12/19/germanpolitician-threatens-fine-facebook-500000-every-time>.

${ }^{100}$ See Annemarie Bridy, 'Internet Payment Blockades' (2015) 67 Florida L Rev 1523. See also Derek E. Bambauer, 'Against Jawboning' (2015) 100 Minnesota L Rev 51 (discussing federal and state governments increasing regulation of on-line content through informal enforcement measures, such as threats, at the edge of or outside their authority).

${ }^{101}$ See Bridy (n 100) 1523. See Also Backpage v. Dart (denying an injunction against Sheriff Dart for his informal efforts to coerce credit card companies into closing their accounts with Backpage).

102 See Commission (n 10) 10-11.

103 ibid 11.
} 
consistency of the European intermediary liability framework. The reform endorses a vertical or sectorial approach, which would inevitably clash with the horizontal eCommerce intermediary liability regime by introducing filtering and proactive monitoring obligation for hosting providers through legislation and voluntary measures. It will affect the system deeply by de facto causing European intermediary liability to shift from a negligence based to a strict liability regime.

This systemic shift would occur lacking both empirical evidence and public consensus. ${ }^{104}$ First, the Commission has apparently based the upcoming reform on content industry assumptions, rather than independent empirical evidence. Whether there is empirical evidence suggesting that creators - and the creative market as a whole- have been slowly withering or rather flourishing should have been at the core of any policy analysis suggesting reform of online platform regulations. Crafting European Digital Single Market policies on the assumption of a 'value gap' to close might undermine evidence showing the platform economy's positive externalities for creativity. As earlier mentioned, nor positive or negative externalities of the reform for the creative market online have been discussed through empirical and economic research. Second, proposed changes in the eCommerce intermediary liability would also conflict with public consensus - as emerged in multiple EU consultations. The course that the Commission has finally taken through a sectorial approach can be hardly reconciled with the bold statement made in the OP\&DSM Communication - and motivated by the results of public consultations - that " $[\mathrm{t}]$ he Commission will maintain the existing intermediary liability regime." 105

The proposed reform aims at promoting private enforcement of illicit conducts online, which is a long-lasting favorite of governments - and right holders. Filtering and monitoring obligations, voluntary measures, strict rather than negligence-based liability might be the weaponry deployed to get the job done in spite of an apparent lack of consensus and empirical evidence for such reforms. Shaking the intermediary liability system from horizontal to vertical might possibly serve as a screen to operate a reform that would be only based on governmental and industry assumptions. Nonetheless, the systemic damages that this earthquake shall produce might break down the eCommerce intermediary liability regime.

\footnotetext{
${ }^{104}$ The EU Parliament might have taken notice of the necessity to legislate about copyright law on the basis of clear empirical evidence by dedicating the $6^{\text {th }}$ edition of the EUhackathon challenge to visualizing empirical evidence for copyright reform. As part of this challenge, a number of software developers have been called to develop tools to visualize copyright empirical evidence. See EUhackathon, 15-16 November 2016 <http://2016.euhackathon.eu>.

${ }^{105}$ OP\&DMS Communication, supra note 26, at 9.
} 